\title{
Ultrasonic Testing of Non-ferrous Materials in the Foundry Industry
}

Radoslav Konar, Marek Patek, Andrej Zrak

Department of Technological Engineering, Faculty of Mechanical Engineering, University of Zilina, Univerzitna 8215/1, 01026 Zilina. Slovak Republic. E-mail: radoslav.konar@fstroj.uniza.sk, marek.patek@fstroj.uniza.sk, andrej.zrak@fstroj.uniza.sk

Article deals with ultrasonic testing of the casting. It focuses on the problems that arise when testing of castings is made of non-ferrous metals. Theoretical introduction of article is dedicated to the most common types of casting defects and selecting technology for their reliable identification. The impact of the large anisotropic grain casting to propagate and attenuation of ultrasound it describes in theory. The examples of practical testing of $\mathrm{Cu}$-alloy casting are presented in experimental part. Modern tools for simulation of ultrasound propagation in testing material were used for the correct setting techniques of UT testing as well as for the evaluation of the measurement results. Conventional direct contact ultrasound probe with frequencies of $5 \mathrm{MHz}, 3.5 \mathrm{MHz}$ and $2 \mathrm{MHz}$ were used for all measurements. The results of experimental measurements referred in this article are recommendations for selecting equipment and accessories for casting testing made of non-ferrous metals.

Keywords: Ultrasonic testing, castings, non-ferrous materials

\section{Acknowledgement}

This work has been supported by the Scientific Grant Agency of the Ministry of Education of the Slovak Republic, grant VEGA: 1/0836/13, KEGA: 034ZU-4/2015 and KEGA: 014ZU-4/2015.

\section{References}

[1] LANGENBERG, K., J., MARKLEIN, R., MAYER, K. (2012). Ultrasonic nondestructive testing of materials Theoretical foundations. pp. 772. CRC Press, New York.

[2] KOPEC, B. et al.: Nondestructive Testing of Materials and Structures, CERM, s.r.o. : Brno, 2008, p. 573, ISBN 978-80-7204-591-4.

[3] ANDROSOVA, Z., SKRBEK, B. (2012). The use of magnetic and ultrasonic structuroscopy for inspection of ADI/AGI castings. In: Manufacturing technology, pp. 93-97. J.E. Purkyne University, Ústi nad Labem.

[4] BRUNA, M., KUCHARCIK, L., SLADEK, A. (2013). Complex evaluation of porosity in A356 alluminium alloy using advanced porosity module. In: Manufacturing technology, Vol. 13, No. 1, pp. 26-30. J.E. Purkyne University, Ústi nad Labem.

[5] RICHTARECH, L., BOLIBRUCHOVA, D. (2014). Efect of Selected Elements on the Microstructure of Secondary Al-Si Alloys. In: Manufacturing technology, Vol. 14, No. 3, pp. 431-437. J.E. Purkyne University, Ústi nad Labem.

[6] NOVAK, P., MESKO, J., ZMINDAK, M. (2011). Finite element implementation of multi-pass fillet weld with phase changes. In: Manufacturing technology, Vol. 13, No. 1, pp. 79-85. J.E. Purkyne University, Ústi nad Labem.

[7] ZMINDAK, M. et al. (2014) Fiite element analysis of crack growth in pipelines. In: Manufacturing technology, Vol. 13, No. 1, pp. 116-122. J.E. Purkyne University, Ústi nad Labem.

[8] MICIAN, M., PATEK, M., SLADEK, G. (2014). Concept of Reapiring Branch Pipes on High-pressure Pipelines by Using split Sleeve. In: Manufacturing technology, Vol. 14, No. 3, pp. 60-66. J.E. Purkyne University, Ústi nad Labem.

[9] DOPJERA, D., MICIAN, M. (2014). The Detection of Artificially Made Defects in Welded Joint with Ultrasonic defectoscopy Phased Array. In: Manufacturing technology, Vol. 14, No. 1, pp. 12-17. J.E. Purkyne University, Ústi nad Labem.

[10] VRZGULA, P., FATURÍK, M., MICIAN, M. (2014). New Inspection Technologies for Identification of Failure in the Materials and Welded Joints for Area of Gas Industry. In: Manufacturing technology, Vol. 14, No. 3, pp. 487-492. J.E. Purkyne University, Ústi nad Labem.

[11] MORAVEC, J., BRADAC, J., NOVAKOVA, I. (2014) Ways of numerical prediction of austenitic grain size in heat-affected zone of welds. In: 7th International Conference on Innovative Technologies for Joining Advanced Materials, TIMA 2014, Trans Tech Publications Ltd.

[12] OLYMPUS (2013). The company Olympus NDT. Online: 〈http://www.olympus-ims.com/cs〉. 